\title{
Roles Of Human Capital And Total Factor Productivity Growth As Sources Of Growth: Empirical Investigation In Thailand
}

\author{
Paitoon Kraipornsak, Chulalongkorn University, Thailand
}

\begin{abstract}
Total Factor Productivity (TFP) growth has long been identified as an exogenous source of economic growth (the residual growth). Recently, there have been a number of economists who introduced and developed the view of endogenous growth model. An argument is that all important factors of source of growth are incorporated into the growth model, there should not present a significant exogenous residual growth. This paper presents an analysis on estimated TFP growth of which it could be considered as a factor of technological progress that is viable in the economy as it is believed. This study included human capital input into the estimated sectoral production function as an essential factor input that can explain capacity of knowledge advancement and an effective innovation in the economy. Human capital is therefore considered to play an essential role in modern growth theory. However, empirically, the effect of human capital on growth and productivity has been inconclusive probably due to the estimation problem. Frequently macroeconomic time series are often non stationary, this study cautiously dealt with the estimation in line with stationary time series econometrics. In this paper, human capital index was constructed based on the Mincerain wage equation and was augmented into the production function for the analysis of growth. The results of the estimation indicated the existence of long run positive contribution of the TFP growth in agriculture but insignificant long run contribution to growth in services. Human capital also positively contributed to growth in agriculture but it was insignificantly contributed to growth in industry and services. Remarkably, physical capital input was found the significant contribution to growth in all sectors. The study also estimated for the economy wide allowing all three sectors to interact among them and found that in the long run growth of industry can be traded off with those of agriculture and services. The TFP growth was also found significantly contributable to the long run growth of the economy. The finding is consistent with the new concept of endogenous growth hypothesis. The conventional concept of the TFP growth estimated from the two input production function was found inadequate to explain the contribution to growth. Human capital was found to be the third factor input that must be included in the estimation of production function. The residual growth or the shift of production function or the TFP growth in this study can mainly be explained by technological progress that is not represented by any other factor of advancement. Nevertheless, this technological progress or the TFP growth must be incorporated and be estimated at the same time in the model but not as being the residual of the regression equation. Therefore, the residual growth in line with the conventional concept must be insignificant. Additionally, because the findings excluded the essential factors, which is human capital input from the estimated standard two factor input models, it caused the residual growth to be significant, as found in the past.
\end{abstract}

Keywords: Total Factor Productivity (TFP) Growth, Residual Growth, Human Capital, Exogenous TFP growth, Endogenous Growth, Non Stationary Time Series.

\section{INTRODUCTION}

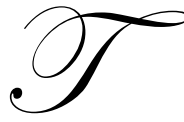

hailand is one of the fast growing economies in the world with an average of 6.2 per cent per annum during 1960 and 2007. Growth obviously accelerated during the late 1980s. High economic growth rates cause real per capita GDP to rise more than 3.3 times in 47 years. Real output has been growing very much faster in nonagricultural sector (25.2 times in 47 years) than in agricultural sector (5.2 times in 47 years). Employment in the recent decade grew by 2 per cent of which was the strongest in non-agriculture ( 2.9 per cent per 
year) compared to merely 0.9 per cent per year in agriculture. Labour force grew only by 0.1 per cent per year. Sustainable growth is therefore a challenge for the Thai economy in current decades.

Several studies on sources of growth have been conducted around the world as well as for Thailand. A number of models of economic growth have been studied and can be traced back to Adam Smith (specialization and learning by doing), the Multhus dismal model (diminishing marginal returns due to a fixed capital factor), the Schumpeterian model of innovation, and the Harrod-Domar model of the role of saving and investment. Solow (1956 and 1957) was one of the neoclassical economists who originally developed a useful framework of the residual growth or later called "total factor productivity (TFP) growth". The shift of production function is to explain for the increase in total factor productivity of the economy of which was exogenously determined in the Solow's residual growth model. Technological progress has been one of the factors to claim for the increase in the TFP and to generate the permanent growth of the economy. Recently, many economists have searched for the causes of growth and have augmented the growth model by adding other possible explanatory variables. Denison (1985) tried to combine information on growth of input factor (labour) in terms of both quantity and quality. He found technological growth did not account for all observed growth. The variation over time of the estimated productivity growth observed in the study pointed out a question of what determined the productivity growth. The endogenous models of technological progress has therefore brought into attention to describe the process under the long run economic growth. The economists in this new growth theory approach include Romer (1990 and 1994).

This study augments human capital into the analytical model of production function. The extension of the production function model to include human capital is to view in fact that this model extension takes a broader view of capital than it was. In the same manner as it is in the regression analysis of time series, the study also accounts that the residual from the estimated econometric model must be a White Noise process. The study explored to see whether the model that incorporates a major input factor; i.e., human capital, can provide a sound econometric model result as well as a confirmation that the TFP growth can be endogenously incorporated into the growth model instead of exogenously given as it was suggested.

\section{TFP GROWTH OF THAILAND}

A number of studies had found the main factor of economic growth in Thailand was capital contribution. Limskul (1988) estimated the TFP growth in Thailand compared to the newly industrializing economies (Japan, China, and Korea (Rep)). There were 4 sectors in the study; i.e., the primary sector; the manufacturing sector (including mining, construction, and transportation), the finance sector; and the service sector. Both CES and VES functional forms of the production function were estimated and applied during 1960 - 1986. The TFP growth was found to be highest in the electricity and water supply sector while it was negative for most sectors of the study. Capital input was the largest contribution to growth which was found similar to the case of Japan,

Tinakorn and Sussangkarn (1998) estimated TFP growth in Thailand using the growth accounting method and based on the Solow-Denison approach, The study estimated for both the aggregate level and the sectoral level. The study also incorporated labour input factor in terms of both change in its quality and quantity. The study classified labour input by age, sex, and level of education and an adjustment was made to construct an index of labour quality. The TFP growth was analyzed taking into account its capacity utilization rate of capital. The conclusion indicated that the contribution of labor and quality were 0.96 (11.9 per cent), 1.80 (22.2 per cent) while it was 5.01 (61.8 per cent) for capital, and 0.03 ( 0.4 per cent) for land respectively during $1980-1995$. It should be noted that the contribution of the adjusted (incorporated quality of labour) TFP growth was 1.3 (15.6 per cent) which was smaller when it was compared to 2.11 ( 26 per cent).of the non adjusted TFP growth.

Kaipornsak (1995) estimated Thailand's TFP growth in 8 economic sectors, 13 industrial sectors, and 5 major crops. The econometric estimation was based on the Cobb-Douglas production function and compared with translog functional form under the constant returns to scale assumption. Results were found consistent with Limskul (1988) that TFP growth contributed most in the electricity and water supply sector. Capital was the largest contributor to growth. He also found that TFP growth showed a declining trend in the manufacturing sector. 
Brimble (1987) estimated TFP growth of 139 companies in 7 industries during 1975-83 using an approach of the translog production function under the constant returns to scale assumption. The study found that growth in input factors of production contributed for 60.2 per cent of the output growth of which 0.7 per cent were from labor factor contribution, 10.8 per cent from capital factor contribution, 48.7 per cent from intermediate factor contribution, and 39.9 per cent from TFP growth contribution. The highest TFP growth was found in the automobile ( 7.6 per cent) and electrical industries ( 6.9 per cent) and lowest in the rubber industry.

Office of the National Economic and Social Development Board has frequently calculated the TFP growth in Thailand using the growth accounting approach assuming that in the equilibrium factor elasticity is equal to factor share. The factors' shares are the weights used in the calculation of the TFP growth as regularly done in the growth accounting framework. It was also found that capital input was the main source of growth in Thailand during the period of the study during $1982-2006$.

Chandrachai, Tubtimthong and Chokpisansin (2004) calculated the TFP growth in Thailand during 1977 99 using the growth accounting method. The study incorporated quality into the labour input by taking into account of age, sex and level of education. The units of efficiency labour input were constructed to adjust for labour quality improvement during the period of the study. The average TFP growth using efficiency units of employment was found to reduce when compared to the TFP growth of those using number of employement units. Capital input was found the highest contributor of the source of growth.

\section{ROLE OF HUMAN CAPITAL IN ECONOMIC GROWTH}

Generally, human capital can be thought as a resource or factor input of production that is an attribute of a person that is productive. As human capital, it can be invested in various ways such as (formal and informal) education, health care, or even learning by doing. With the mention, its returns are in the form of wage, salary, or any other compensation.

Human capital is considered to play an important role in modern growth theory. Empirically, however, the effect of human capital on growth and productivity has been found mixed probably due to the estimation problem. This study is based on the hypothesis that we allow human capital to be incorporated in the model of output growth to reflect its role as an important component of capital input. Mankiw, Romer and Weil (1992) additionally allowed for human capital to play a role and empirically found, using cross countries data, that the finding is encouraging for the human capital model. Lucas (1988) also linked human capital with the TFP growth in his study.

Kim and Lau (1994) implied the role of human capital in their study. They found no technological progress in East Asian developing economies in the period of mid 1990s, the period before the Asian financial crisis. The reason was explained that the technological progress reflects the effect of investment in human capital and research and development (intangible capital). These East Asian countries had however invested little in such capital at that time.

Human capital can be thought of as knowledge gained by human resources. It can be invested just like the creation of physical capital by way of education, training, learning by doing and even health improvement. In this manner, investment in human capital is required to replace expired human capital that has gone away such as those who pass away or are retiring.

Assuming the production function of two major factor input of an economy takes the form of CobbDouglas, the model which adds a human capital input can therefore be written as showed in Equation (1) below.

$Y_{t}=A(t) K_{t}^{\beta_{1}} H_{t}^{\beta_{2}} L_{t}^{1-\beta_{1}-\beta_{2}}$ 
Where

$\mathrm{Y}=$ Output

$\mathrm{K}=$ Physical Capital

$\mathrm{H}=$ Human Capital

$\mathrm{L}=$ Labour

$\beta_{1}$ and $\beta_{2}$ are elasticities of output with respect to physical capital, labour and human capital and $\beta_{1}+\beta_{2}<1$. Here, the growth of three factor inputs and level of technology (A) can be written as the equation below.

$$
\dot{K}_{t}=s_{K} Y_{t} ; \dot{L}_{t}=n L_{t} ; \dot{H}_{t}=s_{H} Y_{t} \text { and } \dot{A(t)}=g A(t)
$$

Where $\dot{K}_{t}=\frac{\partial K_{t}}{\partial t} ; \dot{L}_{t}=\frac{\partial L_{t}}{\partial t} \dot{H}_{t}=\frac{\partial H_{t}}{\partial t} ; \dot{A(t)}=\frac{\partial A(t)}{\partial t}$

Data for human capital can be proxied by various ways as long as it indicates the size of the stock of human that can also be invested and accumulated into the human capital stock. In many studies as well as in Mankiew, Romer and Weil (1992), enrollment levels for secondary education in each country were used for human capital index as there was no measure of human capital for any country.

To examine the role of human capital, this study firstly constructed a simple human capital index for 3 economic sectors (agriculture, industry and services) using the Mincerian approach of wage regression. The concept used in the study shows that human capital and market wage are related as in Equation (3) below.

$W_{t}=p_{t} H_{t}$

Where

$\mathrm{W}_{\mathrm{t}}=$ market wage rate

$\mathrm{p}_{\mathrm{t}}=$ price of skill

$\mathrm{H}_{\mathrm{t}}=$ quantity of skills or human capital

\subsection{Wage equation estimation}

From the above concept, it implies that the growth of wage rate comes from the growth of human capital and its price. Mincer (1974) developed his famous wage equation showing the relationship between wages, schooling, experience, and experience ${ }^{2}$. While education and experience are potential sources of human capital growth of the workforce, this study estimates the wage equation based on these two factors. Due to data limitation, this study regressed wage (W, real earnings per month) on education (ED, years of school attainment), age (Age, a proxy of experience), and Gender (Gend, $=1$, if male) as in Equation (4) below.

$$
\begin{aligned}
& \ln \left(\boldsymbol{W}_{\boldsymbol{i}}\right)=\boldsymbol{\beta}_{0}+\boldsymbol{\beta}_{1} \ln \left(\boldsymbol{E} \boldsymbol{D}_{\boldsymbol{i}}\right)+\boldsymbol{\beta}_{2} \boldsymbol{A} \boldsymbol{g} \boldsymbol{e}_{\boldsymbol{i}}+\boldsymbol{\beta}_{3} \boldsymbol{A g \boldsymbol { e } _ { \boldsymbol { i } } ^ { 2 }}+\boldsymbol{\beta}_{4} \boldsymbol{G e n d}_{\boldsymbol{i}}+\boldsymbol{\alpha}_{1} \boldsymbol{Y} 06 \\
& +\alpha_{2} \boldsymbol{Y} 06 * \ln \left(\boldsymbol{E D}_{\boldsymbol{i}}\right)+\alpha_{3} \boldsymbol{Y} 06 * \boldsymbol{A g e}_{\boldsymbol{i}}+\alpha_{3} \boldsymbol{Y} 06 * \boldsymbol{A g e}^{2}+\alpha_{4} \boldsymbol{Y} 06 * \boldsymbol{G e n d}_{\boldsymbol{i}}+\varepsilon_{i}
\end{aligned}
$$

The study estimated the wage equation using data of individual samples from the Labour Force Survey of the National Statistical Office in year 1993 and 2006 (survey period of round 3). The model is therefore estimated for the two years and implies the change of wage equation from 1993 to 2006. The model was estimated for 3 sectors; i.e., agriculture, industry (including mining and quarrying, manufacturing, and construction) and services (including electricity and water, transportation and communication, commerce and finance, and other services). 
Remark for instance that $\partial \ln \left(\boldsymbol{W}_{\boldsymbol{i}}\right) / \partial \ln \left(\boldsymbol{E} \boldsymbol{D}_{\boldsymbol{i}}\right)=\boldsymbol{\beta}_{1}+\alpha_{2}$ is the effect of education on real wage that was $\beta_{1}$ in 1993 and was $\beta_{1}+\alpha_{2}$ in 2006 or increased by $\alpha_{2}$ within 13 years during the period of the study. By assuming that the effect of change in real wage is a linear form, therefore, the study can estimate the rate of change of the effect of education on wage per year in average. Similarly, the effects of experience (age) and gender (gend) can also be examined in the same manner. Result of the estimation of the wage equation (4) is shown in Table 1 below.

Table 1 Results of the estimation of the wage equation (4)

\begin{tabular}{|c|c|c|c|c|}
\hline \multicolumn{5}{|c|}{$\begin{array}{l}\text { Dependent Variable: LOG(W) } \\
\text { Method: Least Squares }\end{array}$} \\
\hline Variable & Coefficient & Std. Error & t-Statistic & Prob. \\
\hline $\mathrm{C}$ & 8.7428 & 0.6091 & 14.3532 & 0.0000 \\
\hline LOG(ED) & 0.2334 & 0.1956 & 1.1934 & 0.2328 \\
\hline AGE & 0.0502 & 0.0207 & 2.4314 & 0.0151 \\
\hline AGESQ & -0.0007 & 0.0003 & -2.5175 & 0.0118 \\
\hline GEND & 0.4434 & 0.0870 & 5.0979 & 0.0000 \\
\hline Y06 & -1.3744 & 0.6195 & -2.2187 & 0.0265 \\
\hline Y06*LOG(ED) & 0.4661 & 0.1975 & 2.3600 & 0.0183 \\
\hline Y06*AGE & -0.0049 & 0.0213 & -0.2318 & 0.8167 \\
\hline Y06*AGESQ & 0.0003 & 0.0003 & 0.9369 & 0.3488 \\
\hline Y06*GEND & -0.1751 & 0.0889 & -1.9694 & 0.0490 \\
\hline R-squared & 0.1639 & Mean depen & nt var & 9.7738 \\
\hline Adjusted R-squared & 0.1626 & S.D. depend & t var & 0.7366 \\
\hline S.E. of regression & 0.6741 & Akaike info & terion & 2.0508 \\
\hline Sum squared resid & 2648.5640 & Schwarz crit & & 2.0622 \\
\hline Log likelihood & -5977.1950 & F-statistic & & 126.9290 \\
\hline Durbin-Watson stat & 0.2789 & Prob(F-statis & & 0.0000 \\
\hline
\end{tabular}

\subsection{Industry}

\begin{tabular}{lrcrr}
\hline $\begin{array}{l}\text { Dependent Variable: LOG(W) } \\
\text { Method: Least Squares }\end{array}$ & \multicolumn{4}{l}{} \\
\hline \multicolumn{1}{c}{ Variable } & Coefficient & Std. Error & t-Statistic & Prob. \\
\hline C & 8.8872 & 0.3025 & 29.3799 & 0.0000 \\
LOG(ED) & 0.1784 & 0.0945 & 1.8881 & 0.0590 \\
AGE & 0.0643 & 0.0117 & 5.5146 & 0.0000 \\
AGESQ & -0.0010 & 0.0002 & -6.2012 & 0.0000 \\
GEND & 0.5510 & 0.0473 & 11.6462 & 0.0000 \\
Y06 & -0.6266 & 0.3067 & -2.0434 & 0.0410 \\
Y06*LOG(ED) & 0.5688 & 0.0950 & 5.9863 & 0.0000 \\
Y06*AGE & -0.0214 & 0.0119 & -1.7912 & 0.0733 \\
Y06*AGESQ & 0.0007 & 0.0002 & 4.0189 & 0.0001 \\
Y06*GEND & -0.5539 & 0.0473 & -11.7073 & 0.0000 \\
\hline R-squared & 0.2842 & Mean dependent var & 10.7367 \\
Adjusted R-squared & 0.2838 & S.D. dependent var & 0.6174 \\
S.E. of regression & 0.5225 & Akaike info criterion & 1.5401 \\
Sum squared resid & 4724.1130 & Schwarz criterion & 1.5446 \\
Log likelihood & -13324.0200 & F-statistic & 763.5110 \\
Durbin-Watson stat & 0.6412 & Prob(F-statistic) & 0.0000 \\
\hline
\end{tabular}




\subsection{Services}

\begin{tabular}{lrcrr}
\hline $\begin{array}{l}\text { Dependent Variable: LOG(W) } \\
\text { Method: Least Squares }\end{array}$ & \multicolumn{4}{l}{} \\
\hline \multicolumn{1}{c}{ Variable } & Coefficient & Std. Error & t-Statistic & Prob. \\
\hline C & 6.8818 & 0.3940 & 17.4663 & 0.0000 \\
LOG(ED) & 0.8700 & 0.1007 & 8.6394 & 0.0000 \\
AGE & 0.0971 & 0.0185 & 5.2602 & 0.0000 \\
AGESQ & -0.0013 & 0.0003 & -4.8884 & 0.0000 \\
GEND & 0.3878 & 0.0648 & 5.9883 & 0.0000 \\
Y06 & 0.5372 & 0.3965 & 1.3549 & 0.1755 \\
Y06*LOG(ED) & 0.1588 & 0.1010 & 1.5725 & 0.1159 \\
Y06*AGE & -0.0577 & 0.0186 & -3.1026 & 0.0019 \\
Y06*AGESQ & 0.0012 & 0.0003 & 4.4523 & 0.0000 \\
Y06*GEND & -0.2296 & 0.0652 & -3.5244 & 0.0004 \\
\hline R-squared & 0.4917 & Mean dependent var & 11.1360 \\
Adjusted R-squared & 0.4915 & S.D. dependent var & 0.7728 \\
S.E. of regression & 0.5511 & Akaike info criterion & 1.6466 \\
Sum squared resid & 7502.4030 & Schwarz criterion & 1.6499 \\
Log likelihood & -20335.6500 & F-statistic & 2654.8420 \\
Durbin-Watson stat & 0.7427 & Prob(F-statistic) & 0.0000 \\
\hline
\end{tabular}

From the estimations of the 3 sectoral equations, some interesting findings and implications can be concluded as follows:

\section{Agriculture}

1. Real minimum (or lump sum) compensation or earnings (W) was on average of 6,265.41 baht per month (calculated from the intercept). This can be thought of as an effect of a specific factor of sectoral workers in agriculture.

2. In 1993, more education received by workers was found to have insignificant effect on the real worker's earnings in agriculture. It was found to have an increasing effect on earnings in 2006 (or had more return on education received). When a worker has a 1 per cent increase in education attainment level, the earnings in 2006 would increase by 0.46 per cent of his or her return additionally on the effect in 1993.

3. Age may be thought of as the experience workers obtained in their working life. Consistently found in the estimation that the age profile of earnings took the form of an inversed $U$ shape implying a little decline of earnings after a period of working life. However, no significant change on earnings by the effect of more experience in 2006 from 1993 in the agriculture sector was found.

4. Male workers can earn significantly more than female workers as the result of the equation estimation in the agricultural sector. It is interesting to note that this difference in earnings between genders showed a smaller gap in all sectors in 2006.

\section{Industry}

1. Real minimum (or lump sum) earnings (W) were on average of 7,238.72 baht per month (calculated from the intercept). This can be thought of as an effect of a specific factor of workers in the industry. Note that it is larger than those in agriculture.

2. In 1993, education of workers was found to have a significant effect on real worker's earnings in the industry (by 0.18 per cent). Education was also found to have an increasing effect on earnings (or had more return on education received). When a worker has a 1 per cent increase in his or her education attainment level, earnings in 2006 would increase by 0.57 per cent of his or her returns additionally on its effect in 1993. Therefore returns on education in 2006 would become 0.75 per cent more on the earnings compared to 0.18 per cent in 1993. 
3. Consistently found in the estimation that the age profile of earnings took the form of an inversed $U$ shape implying a little decline of earnings after a late period of working life. However, the result showed that the slope $\left(\alpha_{3}\right)$ or curvature of the inversed $U$ curve becoming flatter in the industry recently in 2006.

4. Male workers can earn significantly more than female workers in the industry. It is interesting to note however that, in case of industry, the difference was found becoming close to zero or no difference in 2006.

\section{Services}

1. Real minimum (or lump sum) earnings (W) were on average of 674.38 baht per month (calculated from the intercept). This can be thought of as an effect of a specific factor of workers in industry. It should be noted that the minimum earnings in the service sector was rather small compared to other sectors.

2. In 1993, education was found to have a strong effect ( 0.87 per cent $)$ on the real worker's earnings in services relative to the other two sectors. Education was found to have a little increase in its effect on earnings $\left(\alpha_{2}\right)$ in 2006 . The returns on education in 2006 increased earnings by 0.16 per cent additionally on its effect in 1993. Therefore, the returns on education in 2006 would become 1.03 per cent on the previous earnings in 1993.

3. Consistently found in the estimation is that the effect of experience on earnings took the form of an inversed $U$ shape. As well as being found in the industry, the slope $\left(\alpha_{3}\right)$ or curvature of the inversed $U$ curve indicated to becoming flatter in the industry recently in 2006.

4. Male workers can earn significantly more than female workers in services. The difference gap $\left(\alpha_{4}\right)$ was found less in 2006.

\subsection{Human capital index}

By assuming that education and experience are factors of investment in human capital, the study took the estimated wage equation to generate the human capital index for the three sectors during 1993:1 to 2006:4. Education and experience variables of workers for each quarter in each sector were then calculated for the human capital index using parameters in the estimated model of earnings by giving the index equal to 100 for the initial year in 1993:1. Results from the calculation of the human capital index for the three sectors are shown in Figure 1 below.

Figure 1 Sectoral Human Capital Index (1993.1 - 2006.4)

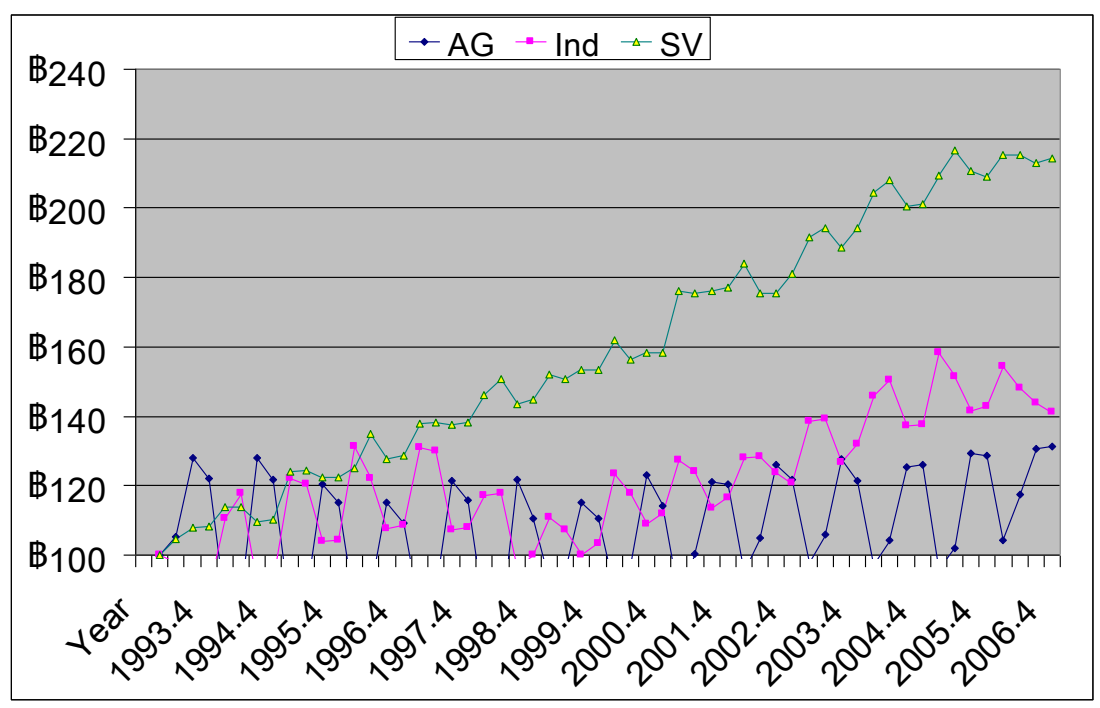

Source: Author's calcalation 


\section{SECTORAL PRODUCTION FUNCTION AND SOURCES OF GROWTH}

The model of growth in the study introduced technological changes through 3 most important factors of input; i.e., physical capital, human capital and labour. The production function can then be shown as in Equation (5) below.

$Y_{t}=A(t) e^{\varepsilon_{t}} f\left(K_{t}, H_{t}, L_{t}\right)$

Where

$\mathrm{Y}=$ output

$\mathrm{K}=$ physical capital

$\mathrm{H}=$ human capital

$\mathrm{L}=$ labour

$\mathrm{A}(\mathrm{t})=$ technology as a function of time

The Cobb Douglas was used in the empirical study as it is a well known simple functional form that obeys all properties of the production function. In addition, it requires not too many variables involved in the econometric estimation while the data is available in quite a limited length of time series. Hence the production function is written as in Equation (6).

$Y_{t}=A_{0} e^{\alpha t+\varepsilon} K^{\beta_{K}} H^{\beta_{H}} L^{\beta_{L}}$

Taking logarithmic of Equation (7) obtain

$\ln \left(Y_{t}\right)=\gamma+\alpha t+\beta_{K} \ln \left(K_{t}\right)+\beta_{H} \ln \left(H_{t}\right)+\beta_{L} \ln \left(L_{t}\right)+\varepsilon_{t}$

Here $\quad \alpha=$ TFP growth which is fixed

$\varepsilon_{\mathrm{t}}=$ Residual of the estimated model that obeys the classical assumption of estimation

\subsection{Data and Stationary Test}

There are 3 economic sectors; i.e., agriculture, industry and services classified in the study. Econometrics of time series was pursued in this study. Data of GDP (at constant prices), net capital stock (at constant prices) were drawn from the National Economic and Social Development Board. The Number of employed workers was extracted from survey data records of the National Statistical Office. Human capital is the human capital index constructed in this study discussed earlier. The data used in the study is during 1993 quarter 1 to 2006 quarter 4 .

As the data used here is in time series, the study conducted the test for unit root of all variables involved. Augmented Dickey Fuller Test for unit root was used to test and found that most of the variables were Non Stationary process and I(1) (see Table 2).

When the data is non stationary process, it is possible to find a spurious relationship between those time series. In order to get the precise results from the estimation of TFP growth, the study has to avoid the spurious regression problem.

When all variables are non stationary (I(1)) and if cointegration is found, there exists a long run relationship between them. The unit root test of the residuals from the sectoral production function as shown in Equation (8) and (9) were carried out to see if the cointegration exists. The approach of vector error correction mechanism model of the multivariate time series was used to show if there is a long run relationship or the role of human capital and the TFP growth in the three sectoral growth models. 
Table 2 ADF Test for Unit Root

\begin{tabular}{|c|c|c|c|c|c|c|c|c|c|c|}
\hline $\begin{array}{c}\text { Sector/ } \\
\text { Variabl } \\
\text { e } \\
\end{array}$ & $\begin{array}{c}\text { \# lag } \\
\text { length of } \\
\text { level }\end{array}$ & $\begin{array}{l}\text { Inter } \\
\text {-cept }\end{array}$ & trend & $\begin{array}{c}\text { ADF } \\
\text { P-value }\end{array}$ & $\begin{array}{c}\text { \# lag } \\
\text { length of } \\
\mathbf{1}^{\text {st }} \text { Diff }\end{array}$ & $\begin{array}{l}\text { Inter } \\
\text {-cept }\end{array}$ & $\begin{array}{c}\text { ADF } \\
\text { P-value }\end{array}$ & $\begin{array}{l}\text { Inter } \\
\text {-cept }\end{array}$ & $\begin{array}{c}\text { \# lag } \\
\text { length of } \\
2^{\text {nd }} \text { Diff }\end{array}$ & $\begin{array}{c}\text { ADF } \\
\text { P-value }\end{array}$ \\
\hline \multicolumn{11}{|c|}{ Agriculture } \\
\hline $\mathrm{Y}$ & 4 & yes & yes & 0.2135 & 3 & yes & 0.0007 & - & - & - \\
\hline $\mathrm{K}$ & 1 & yes & yes & 0.2885 & 0 & no & 0.1534 & no & 0 & 0.0000 \\
\hline $\mathrm{H}$ & 3 & yes & yes & 0.0176 & & & & - & - & - \\
\hline $\mathrm{L}$ & 3 & yes & no & 0.0001 & - & - & - & - & - & - \\
\hline \multicolumn{11}{|c|}{ Industry } \\
\hline $\mathrm{Y}$ & 5 & no & no & 0.9779 & 4 & no & 0.0120 & - & - & - \\
\hline $\mathrm{K}$ & 1 & yes & no & 0.2764 & 0 & yes & 0.0000 & - & - & - \\
\hline $\mathrm{H}$ & 5 & yes & yes & 0.2068 & 5 & no & 0.0453 & - & - & - \\
\hline $\mathrm{L}$ & 6 & yes & no & 0.3192 & 5 & no & 0.0277 & - & - & - \\
\hline
\end{tabular}

\begin{tabular}{|c|c|c|c|c|c|c|c|c|c|c|}
\hline Services & & & & & & & & & & \\
\hline $\mathrm{Y}$ & 4 & yes & yes & 0.6514 & 3 & no & 0.0204 & - & - & - \\
\hline $\mathrm{K}$ & 8 & yes & yes & 0.0001 & - & - & - & - & - & - \\
\hline $\mathrm{H}$ & 3 & yes & no & 0.2558 & 2 & yes & 0.0000 & - & - & - \\
\hline $\mathrm{L}$ & 8 & yes & yes & 0.4079 & 7 & yes & 0.1825 & 6 & no & 0.0000 \\
\hline
\end{tabular}

Note: 1. all are in logarithmic form

2. \# lag length is based on SIC

\subsection{The Model}

The vector error correction mechanism (VECM) approach was applied to the production function as shown in Equation (10) below. Since the study uses quarterly data, it is therefore allowed for time difference of every 4 quarters' lag length or higher order in the short run dynamic (the difference terms in the VECM equations) as shown in Equation (9). The higher than four of the lag lengths would be used in the model until no autocorrelation of the residual were found. In addition, as the capital input in agriculture and labour input in the services were found to be I(2), the first difference term of these two variables were used in the VECM Equation (8) in the two sectors. In order to find the estimation result that conforms to Equation (7) above, we choose the option in the estimation that the cointegrating equation has a linear trend. The study then can test to confirm the role of the TFP growth whether the linear trend is statistically significant.

$$
\begin{aligned}
& \Delta \log \left(\boldsymbol{Y}_{\boldsymbol{t}}\right)=\boldsymbol{\gamma}_{1}+\boldsymbol{\beta}_{1 \boldsymbol{Y}}^{1} \Delta \log \left(\boldsymbol{Y}_{\boldsymbol{t}-4}\right)+\boldsymbol{\beta}_{2}^{1} \boldsymbol{K} \log \left(\boldsymbol{K}_{\boldsymbol{t}-4}\right)+\boldsymbol{\beta}_{3}^{1} \boldsymbol{H}^{\Delta} \log \left(\boldsymbol{H}_{\boldsymbol{t}-4}\right) \\
& +\boldsymbol{\beta}_{4 \mathrm{~L}}^{1} \Delta \log \left(\boldsymbol{L}_{\boldsymbol{t}-4}\right)+\boldsymbol{\lambda}\left(\log \left(\boldsymbol{Y}_{\boldsymbol{t}-1}\right)-\boldsymbol{\delta}_{\boldsymbol{K}} \log \left(\boldsymbol{K}_{\boldsymbol{t}-1}\right)-\boldsymbol{\delta}_{\boldsymbol{H}} \log \left(\boldsymbol{H}_{\boldsymbol{t}-1}\right)\right. \\
& \left.-\delta_{L} \log \left(L_{t-1}\right)+\alpha_{1} t\right)+\varepsilon_{1 t} \\
& \log \left(\boldsymbol{K}_{\boldsymbol{t}}\right)=\boldsymbol{\gamma}_{2}+\boldsymbol{\beta}_{1}^{2} \boldsymbol{Y}_{\boldsymbol{\Delta}} \boldsymbol{\Delta} \log \left(\boldsymbol{Y}_{\boldsymbol{t}-4}\right)+\boldsymbol{\beta}_{2}^{2} \boldsymbol{K}_{\boldsymbol{\Delta}} \boldsymbol{\operatorname { l o g }}\left(\boldsymbol{K}_{\boldsymbol{t}-4}\right)+\boldsymbol{\beta}_{3}^{2}{ }_{\boldsymbol{H}} \boldsymbol{\Delta} \log \left(\boldsymbol{H}_{\boldsymbol{t}-4}\right) \\
& +\boldsymbol{\beta}_{4 \mathrm{~L}}^{2} \Delta \log \left(\boldsymbol{L}_{\boldsymbol{t}-4}\right)+\boldsymbol{\lambda}\left(\log \left(\boldsymbol{Y}_{\boldsymbol{t}-1}\right)-\boldsymbol{\delta}_{\boldsymbol{K}} \log \left(\boldsymbol{K}_{\boldsymbol{t}-1}\right)-\boldsymbol{\delta}_{\boldsymbol{H}} \log \left(\boldsymbol{H}_{\boldsymbol{t}-1}\right)\right. \\
& \left.-\delta_{\mathrm{L}} \log \left(\mathrm{L}_{\mathrm{t}-1}\right)+\alpha_{2} t\right)+\varepsilon_{2 t} \\
& \log \left(\boldsymbol{H}_{\boldsymbol{t}}\right)=\boldsymbol{\gamma}_{3}+\boldsymbol{\beta}_{1}^{3}{ }_{\boldsymbol{Y}} \boldsymbol{\Delta} \log \left(\boldsymbol{Y}_{\boldsymbol{t}-4}\right)+\boldsymbol{\beta}_{2}^{3}{ }_{\boldsymbol{K}} \boldsymbol{\Delta} \log \left(\boldsymbol{K}_{\boldsymbol{t}-4}\right)+\boldsymbol{\beta}_{3}^{3}{ }_{\boldsymbol{H}} \boldsymbol{\Delta} \log \left(\boldsymbol{H}_{\boldsymbol{t}-4}\right) \\
& +\boldsymbol{\beta}_{4 \mathrm{~L}}^{3} \Delta \log \left(\boldsymbol{L}_{\boldsymbol{t}-4}\right)+\boldsymbol{\lambda}\left(\log \left(\boldsymbol{Y}_{\boldsymbol{t}-1}\right)-\boldsymbol{\delta}_{\boldsymbol{K}} \log \left(\boldsymbol{K}_{\boldsymbol{t}-1}\right)-\boldsymbol{\delta}_{\boldsymbol{H}} \log \left(\boldsymbol{H}_{\boldsymbol{t}-1}\right)\right. \\
& \left.-\delta_{\mathrm{L}} \log \left(\mathrm{L}_{\mathrm{t}-1}\right)+\alpha_{2} t\right)+\varepsilon_{3 t} \\
& \log \left(\boldsymbol{L}_{\boldsymbol{t}}\right)=\boldsymbol{\gamma}_{4}+\boldsymbol{\beta}_{1}^{4}{ }_{\boldsymbol{Y}} \boldsymbol{\Delta} \log \left(\boldsymbol{Y}_{\boldsymbol{t}-4}\right)+\boldsymbol{\beta}_{2}^{4} \boldsymbol{K}^{\Delta} \log \left(\boldsymbol{K}_{\boldsymbol{t}-4}\right)+\boldsymbol{\beta}_{3}^{4}{ }_{\boldsymbol{H}} \boldsymbol{\Delta} \log \left(\boldsymbol{H}_{\boldsymbol{t}-4}\right) \\
& +\boldsymbol{\beta}_{4}^{4}{ }_{\mathrm{L}} \Delta \log \left(\boldsymbol{L}_{\boldsymbol{t}-4}\right)+\boldsymbol{\lambda}\left(\log \left(\boldsymbol{Y}_{\boldsymbol{t}-1}\right)-\boldsymbol{\delta}_{\boldsymbol{K}} \log \left(\boldsymbol{K}_{t-1}\right)-\boldsymbol{\delta}_{\boldsymbol{H}} \log \left(\boldsymbol{H}_{\boldsymbol{t}-1}\right)\right. \\
& \left.-\delta_{\mathrm{L}} \log \left(\mathrm{L}_{\mathrm{t}-1}\right)+\alpha_{2} t\right)+\varepsilon_{4 t}
\end{aligned}
$$


Equation (8) represents a dynamic model of the production function (Equation (7)) that we can identify the role of human capital, TFP growth, and the contribution of other inputs in the economic growth. The Johansen Cointegration test (both Trace test and Max-eigenvalue test) indicated 3 cointegrating equations for agriculture and industry, and 2 coinetgrating equations for services. The study, however, focused only on one cointegrating equation for all 3 sectors since it is unclear economic meaning for the other cointegrating equations.

For the whole economy, the study allowed possible interactions among the three economic sectors in the economy that jointly determine their productions in the long run. The model for the whole economy was therefore estimated by treating the output of the three sectors to be endogenous in the VECM model. The Johansen Cointegration test (both Trace test and Max-eigenvalue test) indicated 1 cointegrating equation. Results of the estimation are shown in Table 4 below. Results of the three sectoral estimations are as follows:

\subsection{Agriculture}

In agriculture (Table 3.1), the study found all long run variables significant. While physical capital and human capital were found significantly contributing to growth, labour was found negatively contributing perhaps due to the declining workers in the farms as recently realized. Surprisingly, the contribution of the TFP growth was found to be negative. This requires attention for agricultural development in Thailand. Most estimated coefficients in the short run were insignificant implying unclear relationships between factor inputs and sectoral output in the short run and the adjustment mechanism works to adjust the production function itself to the equilibrium.

It should be noted that there was no land factor input included in this model due to unavailability of quarterly data. The exclusion of land could cause in biasness of the estimation result and perhaps could explain some surprising results above. The autocorrelation LM test was conducted and no autocorrelation was found.

Table 3.1 VECM estimation results of agriculture

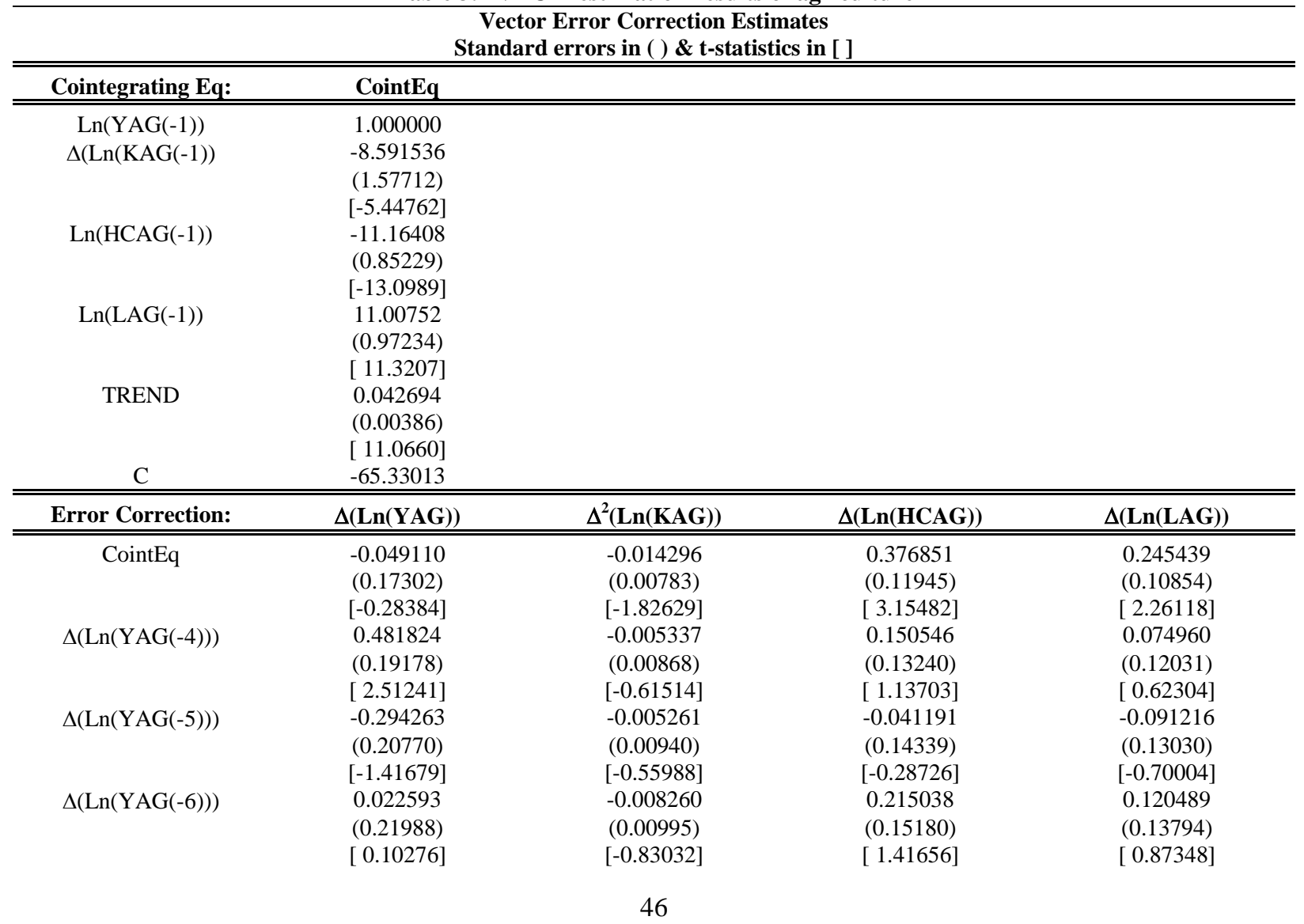


Table 3.1 VECM estimation results of agriculture continued

\begin{tabular}{|c|c|c|c|c|}
\hline $\begin{array}{l}\text { Error Correction: } \\
\end{array}$ & $\Delta(\mathbf{L n}(\mathbf{Y A G}))$ & $\Delta^{2}(\operatorname{Ln}(\mathrm{KAG}))$ & $\Delta(\operatorname{Ln}($ HCAG $))$ & $\Delta(\operatorname{Ln}(\mathbf{L A G}))$ \\
\hline \multirow[t]{3}{*}{$\Delta(\operatorname{Ln}(\mathrm{YAG}(-7)))$} & -0.002751 & -0.004458 & 0.239760 & 0.148347 \\
\hline & $(0.21380)$ & $(0.00967)$ & $(0.14760)$ & $(0.13413)$ \\
\hline & {$[-0.01287]$} & {$[-0.46087]$} & [ 1.62434$]$ & [ 1.10602$]$ \\
\hline \multirow{3}{*}{$\Delta(\operatorname{Ln}(\mathrm{YAG}(-8)))$} & 0.162715 & -0.006675 & 0.070928 & 0.020729 \\
\hline & $(0.19340)$ & $(0.00875)$ & $(0.13352)$ & $(0.12133)$ \\
\hline & [ 0.84136$]$ & {$[-0.76285]$} & {$[0.53121]$} & {$[0.17085]$} \\
\hline \multirow[t]{3}{*}{$\Delta^{2}(\operatorname{Ln}(\mathrm{KAG}(-4)))$} & -1.011840 & -0.261944 & -3.295534 & -4.045272 \\
\hline & $(4.18114)$ & $(0.18917)$ & $(2.88666)$ & $(2.62308)$ \\
\hline & {$[-0.24200]$} & {$[-1.38469]$} & {$[-1.14164]$} & {$[-1.54219]$} \\
\hline \multirow[t]{3}{*}{$\Delta^{2}(\operatorname{Ln}(\mathrm{KAG}(-5)))$} & -3.317023 & 0.056779 & -3.637563 & -3.771698 \\
\hline & (4.29868) & $(0.19449)$ & $(2.96781)$ & (2.69682) \\
\hline & {$[-0.77164]$} & [ 0.29194$]$ & {$[-1.22567]$} & {$[-1.39857]$} \\
\hline \multirow[t]{3}{*}{$\Delta^{2}(\operatorname{Ln}(\mathrm{KAG}(-6)))$} & -6.557258 & -0.144767 & 12.77340 & 11.50531 \\
\hline & $(4.01817)$ & $(0.18180)$ & $(2.77415)$ & $(2.52084)$ \\
\hline & {$[-1.63190]$} & {$[-0.79631]$} & [ 4.60444] & [ 4.56408$]$ \\
\hline \multirow{3}{*}{$\Delta^{2}(\operatorname{Ln}(\mathrm{KAG}(-7)))$} & 4.339673 & -0.270350 & 3.230879 & 1.176890 \\
\hline & $(5.13980)$ & $(0.23255)$ & $(3.54852)$ & $(3.22450)$ \\
\hline & [ 0.84433$]$ & {$[-1.16257]$} & [ 0.91049$]$ & [ 0.36498$]$ \\
\hline \multirow[t]{3}{*}{$\Delta^{2}(\operatorname{Ln}(\mathrm{KAG}(-8)))$} & -1.064305 & -0.744989 & 6.382537 & 4.664087 \\
\hline & $(5.26517)$ & $(0.23822)$ & $(3.63507)$ & (3.30315) \\
\hline & {$[-0.20214]$} & {$[-3.12735]$} & [ 1.75582$]$ & [ 1.41201$]$ \\
\hline \multirow{3}{*}{$\Delta(\operatorname{Ln}(\operatorname{HCAG}(-4)))$} & 0.264398 & 0.126435 & -0.421936 & -0.274002 \\
\hline & $(1.53791)$ & $(0.06958)$ & (1.06177) & $(0.96482)$ \\
\hline & [ 0.17192] & [ 1.81709$]$ & {$[-0.39739]$} & {$[-0.28399]$} \\
\hline \multirow[t]{3}{*}{$\Delta(\operatorname{Ln}(\operatorname{HCAG}(-5)))$} & 2.807568 & 0.066045 & 2.562250 & 2.407849 \\
\hline & $(1.48784)$ & $(0.06732)$ & $(1.02720)$ & $(0.93341)$ \\
\hline & [ 1.88701$]$ & [ 0.98113$]$ & [ 2.49439] & [ 2.57963] \\
\hline \multirow[t]{3}{*}{$\Delta(\operatorname{Ln}(\operatorname{HCAG}(-6)))$} & -0.305411 & 0.007673 & 0.459482 & 0.314408 \\
\hline & (1.51116) & $(0.06837)$ & $(1.04331)$ & $(0.94804)$ \\
\hline & {$[-0.20210]$} & {$[0.11222]$} & {$[0.44041]$} & {$[0.33164]$} \\
\hline \multirow[t]{3}{*}{$\Delta(\operatorname{Ln}(\operatorname{HCAG}(-7)))$} & -1.476807 & -0.049882 & -0.087845 & -0.354087 \\
\hline & $(1.89503)$ & $(0.08574)$ & $(1.30833)$ & $(1.18886)$ \\
\hline & {$[-0.77931]$} & {$[-0.58179]$} & {$[-0.06714]$} & {$[-0.29784]$} \\
\hline \multirow[t]{3}{*}{$\Delta(\operatorname{Ln}(\operatorname{HCAG}(-8)))$} & 1.397954 & -0.032138 & 1.084201 & 0.738142 \\
\hline & $(1.67161)$ & $(0.07563)$ & $(1.15408)$ & $(1.04870)$ \\
\hline & [ 0.83629$]$ & {$[-0.42494]$} & [ 0.93945$]$ & [ 0.70387$]$ \\
\hline \multirow[t]{3}{*}{$\Delta(\operatorname{Ln}(\operatorname{LAG}(-4)))$} & 0.065226 & -0.141991 & 0.959278 & 0.767811 \\
\hline & $(1.75597)$ & $(0.07945)$ & $(1.21232)$ & $(1.10163)$ \\
\hline & {$[0.03715]$} & {$[-1.78724]$} & [ 0.79127$]$ & [ 0.69698$]$ \\
\hline \multirow[t]{3}{*}{$\Delta(\operatorname{Ln}(\operatorname{LAG}(-5)))$} & -1.918186 & -0.058442 & -2.753876 & -2.573214 \\
\hline & $(1.57635)$ & $(0.07132)$ & $(1.08831)$ & $(0.98894)$ \\
\hline & {$[-1.21685]$} & {$[-0.81943]$} & {$[-2.53041]$} & {$[-2.60200]$} \\
\hline \multirow[t]{3}{*}{$\Delta(\operatorname{Ln}(\operatorname{LAG}(-6)))$} & 1.103808 & 0.003277 & -0.535488 & -0.332906 \\
\hline & $(1.65371)$ & $(0.07482)$ & $(1.14172)$ & $(1.03747)$ \\
\hline & [ 0.66747$]$ & [0.04380] & {$[-0.46902]$} & {$[-0.32088]$} \\
\hline \multirow[t]{3}{*}{$\Delta(\operatorname{Ln}(\operatorname{LAG}(-7)))$} & 1.992563 & 0.075184 & -0.352039 & 0.032827 \\
\hline & $(2.09758)$ & $(0.09490)$ & $(1.44817)$ & $(1.31593)$ \\
\hline & [ 0.94994] & [ 0.79222$]$ & {$[-0.24309]$} & {$[0.02495]$} \\
\hline \multirow{3}{*}{$\Delta(\operatorname{Ln}(\operatorname{LAG}(-8)))$} & -1.523596 & 0.043057 & -0.980948 & -0.583407 \\
\hline & $(1.83372)$ & $(0.08296)$ & $(1.26600)$ & $(1.15040)$ \\
\hline & {$[-0.83088]$} & [ 0.51898$]$ & {$[-0.77484]$} & {$[-0.50714]$} \\
\hline \multirow[t]{3}{*}{$\mathrm{C}$} & -0.004701 & -0.000364 & -0.014889 & -0.012954 \\
\hline & $(0.02181)$ & $(0.00099)$ & $(0.01506)$ & $(0.01368)$ \\
\hline & {$[-0.21549]$} & {$[-0.36836]$} & {$[-0.98864]$} & {$[-0.94663]$} \\
\hline
\end{tabular}

\subsection{Industry}

In industry (Table 3.2), the study found physical capital and the TFP growth playing a significant and positive role in the growth of output in the long run. Human capital was found positively but insignificantly 
contributing to its output. Similarly to that finding in agriculture, the relationships between factor inputs and sectoral output were mostly found insignificant in the short run indicating unclear relationship and the adjustment mechanism works to adjust the production function itself to the equilibrium. The role of the TFP growth and physical capital were important to growth in industry. The autocorrelation LM test was conducted and no autocorrelation was found.

Table 3.2 VECM estimation results of industry

\section{Vector Error Correction Estimates}

Standard errors in ( ) \& t-statistics in [ ]

\begin{tabular}{|c|c|c|c|c|}
\hline Cointegrating Eq: & CointEq & & & \\
\hline $\operatorname{Ln}(\mathrm{YIND}(-1))$ & 1.000000 & & & \\
\hline \multirow[t]{3}{*}{$\operatorname{Ln}(\operatorname{KIND}(-1))$} & -0.589023 & & & \\
\hline & $(0.07474)$ & & & \\
\hline & {$[-7.88099]$} & & & \\
\hline \multirow[t]{3}{*}{$\operatorname{Ln}(\operatorname{HCIND}(-1))$} & -0.398752 & & & \\
\hline & $(0.39008)$ & & & \\
\hline & {$[-1.02222]$} & & & \\
\hline \multirow[t]{3}{*}{$\operatorname{Ln}(\operatorname{LIND}(-1))$} & 0.256420 & & & \\
\hline & $(0.35943)$ & & & \\
\hline & [ 0.71341$]$ & & & \\
\hline \multirow[t]{3}{*}{ TREND } & -0.005953 & & & \\
\hline & $(0.00194)$ & & & \\
\hline & {$[-3.06523]$} & & & \\
\hline $\mathrm{C}$ & -4.369770 & & & \\
\hline Error Correction: & $\Delta(\operatorname{Ln}($ YIND $))$ & $\Delta(\operatorname{Ln}($ KIND $))$ & $\Delta(\operatorname{Ln}($ HCIND $))$ & $\Delta(\operatorname{Ln}(\operatorname{LIND}))$ \\
\hline \multirow[t]{3}{*}{ CointEq } & 0.016856 & 0.109585 & 0.093551 & 0.095205 \\
\hline & $(0.05010)$ & $(0.00629)$ & $(0.06719)$ & $(0.06500)$ \\
\hline & [ 0.33642$]$ & [ 17.4296] & [ 1.39242$]$ & [ 1.46463$]$ \\
\hline \multirow[t]{3}{*}{$\Delta(\operatorname{Ln}(\mathrm{YIND}(-4)))$} & 0.353177 & 0.007140 & -0.174297 & -0.233389 \\
\hline & $(0.13119)$ & $(0.01646)$ & $(0.17592)$ & $(0.17021)$ \\
\hline & [ 2.69203$]$ & [ 0.43367$]$ & {$[-0.99075]$} & {$[-1.37121]$} \\
\hline \multirow[t]{3}{*}{$\Delta(\operatorname{Ln}(\mathrm{YIND}(-5)))$} & -0.323177 & -0.023943 & -0.197883 & -0.210409 \\
\hline & $(0.12820)$ & $(0.01609)$ & $(0.17191)$ & $(0.16633)$ \\
\hline & {$[-2.52081]$} & {$[-1.48824]$} & {$[-1.15106]$} & {$[-1.26502]$} \\
\hline \multirow[t]{3}{*}{$\Delta(\operatorname{Ln}(\operatorname{KIND}(-4)))$} & -0.158718 & 0.021440 & -0.528742 & -0.547372 \\
\hline & $(0.12805)$ & $(0.01607)$ & $(0.17170)$ & $(0.16612)$ \\
\hline & {$[-1.23954]$} & [ 1.33436$]$ & {$[-3.07941]$} & {$[-3.29498]$} \\
\hline \multirow[t]{3}{*}{$\Delta(\operatorname{Ln}(\operatorname{KIND}(-5)))$} & -0.048344 & 0.017698 & -0.844714 & -0.856162 \\
\hline & $(0.12004)$ & $(0.01506)$ & $(0.16096)$ & $(0.15573)$ \\
\hline & {$[-0.40275]$} & [ 1.17496 ] & {$[-5.24791]$} & {$[-5.49767]$} \\
\hline \multirow[t]{3}{*}{$\Delta(\operatorname{Ln}(\operatorname{HCIND}(-4))$} & -0.184974 & 0.038711 & -1.076526 & -1.786049 \\
\hline & $(0.40806)$ & $(0.05121)$ & $(0.54718)$ & $(0.52940)$ \\
\hline & {$[-0.45330]$} & {$[0.75600]$} & {$[-1.96740]$} & {$[-3.37371]$} \\
\hline \multirow[t]{3}{*}{$\Delta(\operatorname{Ln}(\operatorname{HCIND}(-5)))$} & 0.736453 & 0.087538 & 0.061334 & -0.001476 \\
\hline & $(0.43468)$ & $(0.05455)$ & $(0.58289)$ & $(0.56395)$ \\
\hline & [ 1.69423$]$ & [ 1.60483$]$ & {$[0.10523]$} & {$[-0.00262]$} \\
\hline \multirow[t]{3}{*}{$\Delta(\operatorname{Ln}(\operatorname{LIND}(-4)))$} & 0.210501 & -0.041025 & 1.725887 & 2.465842 \\
\hline & $(0.37496)$ & $(0.04705)$ & $(0.50280)$ & $(0.48646)$ \\
\hline & {$[0.56140]$} & {$[-0.87190]$} & [ 3.43254$]$ & [ 5.06892$]$ \\
\hline \multirow[t]{3}{*}{$\Delta(\operatorname{Ln}(\operatorname{LIND}(-5)))$} & -0.714902 & -0.079557 & -0.009063 & 0.041493 \\
\hline & $(0.40863)$ & $(0.05128)$ & $(0.54795)$ & $(0.53015)$ \\
\hline & {$[-1.74950]$} & {$[-1.55150]$} & {$[-0.01654]$} & [ 0.07827$]$ \\
\hline \multirow[t]{3}{*}{$\mathrm{C}$} & 0.010591 & 0.010291 & 0.026208 & 0.026546 \\
\hline & $(0.00603)$ & $(0.00076)$ & $(0.00809)$ & $(0.00782)$ \\
\hline & [ 1.75623$]$ & [ 13.5988] & [3.24078] & [3.39290] \\
\hline
\end{tabular}


Table 3.3 VECM estimation results of services

Vector Error Correction Estimates

Standard errors in ( ) \& t-statistics in [ ]

\begin{tabular}{|c|c|c|c|c|}
\hline Cointegrating Eq: & CointEq & & & \\
\hline $\operatorname{Ln}(Y S V(-1))$ & 1.000000 & & & \\
\hline \multirow[t]{3}{*}{$\operatorname{Ln}(\operatorname{KSV}(-1))$} & -0.972729 & & & \\
\hline & $(0.11964)$ & & & \\
\hline & {$[-8.13068]$} & & & \\
\hline \multirow[t]{3}{*}{$\operatorname{Ln}(\operatorname{HCSV}(-1))$} & -0.184293 & & & \\
\hline & $(0.14218)$ & & & \\
\hline & {$[-1.29623]$} & & & \\
\hline \multirow{3}{*}{$\Delta(\operatorname{Ln}(\operatorname{LSV}(-1))$} & -0.674740 & & & \\
\hline & $(0.12608)$ & & & \\
\hline & {$[-5.35180]$} & & & \\
\hline \multirow[t]{3}{*}{ TREND } & -0.002760 & & & \\
\hline & $(0.00193)$ & & & \\
\hline & {$[-1.42741]$} & & & \\
\hline $\mathrm{C}$ & 3.497440 & & & \\
\hline Error Correction: & $\Delta(\mathbf{L n}(\mathbf{Y S V}))$ & $\Delta(\operatorname{Ln}(\mathrm{KSV}))$ & $\Delta(\operatorname{Ln}($ HCSV $))$ & $\Delta^{2}(\operatorname{Ln}(\mathbf{L S V}))$ \\
\hline \multirow[t]{3}{*}{ CointEq } & 0.036138 & 0.068103 & 0.025523 & 0.185898 \\
\hline & $(0.09683)$ & $(0.00883)$ & $(0.09080)$ & $(0.14021)$ \\
\hline & [ 0.37322$]$ & [ 7.71115] & [ 0.28108$]$ & [ 1.32584$]$ \\
\hline \multirow[t]{3}{*}{$\Delta(\operatorname{Ln}(\mathrm{YSV}(-4)))$} & 0.559647 & 0.013113 & -0.000557 & 0.180052 \\
\hline & $(0.19321)$ & $(0.01762)$ & $(0.18118)$ & $(0.27977)$ \\
\hline & [ 2.89663] & {$[0.74410]$} & {$[-0.00308]$} & [ 0.64357$]$ \\
\hline \multirow[t]{3}{*}{$\Delta(\operatorname{Ln}(\mathrm{YSV}(-5)))$} & 0.298305 & 0.012784 & 0.063765 & 0.130572 \\
\hline & $(0.17546)$ & $(0.01600)$ & $(0.16454)$ & $(0.25408)$ \\
\hline & [ 1.70012$]$ & [ 0.79883$]$ & [ 0.38753$]$ & {$[0.51391]$} \\
\hline \multirow[t]{3}{*}{$\Delta(\operatorname{Ln}(\mathrm{YSV}(-6)))$} & -0.065805 & 0.012276 & 0.051414 & 0.133047 \\
\hline & $(0.16593)$ & $(0.01513)$ & $(0.15560)$ & $(0.24027)$ \\
\hline & {$[-0.39659]$} & [ 0.81111$]$ & [ 0.33042$]$ & {$[0.55373]$} \\
\hline \multirow[t]{3}{*}{$\Delta(\operatorname{Ln}(\mathrm{YSV}(-7)))$} & -0.230094 & -0.003737 & -0.073053 & -0.299491 \\
\hline & $(0.18469)$ & $(0.01685)$ & $(0.17320)$ & $(0.26744)$ \\
\hline & {$[-1.24585]$} & {$[-0.22181]$} & {$[-0.42180]$} & {$[-1.11985]$} \\
\hline \multirow[t]{3}{*}{$\Delta(\operatorname{Ln}(\operatorname{KSV}(-4)))$} & -4.792592 & 0.060567 & -1.317836 & -6.766999 \\
\hline & (2.63588) & $(0.24042)$ & $(2.47184)$ & $(3.81688)$ \\
\hline & {$[-1.81821]$} & [ 0.25192$]$ & {$[-0.53314]$} & {$[-1.77292]$} \\
\hline \multirow[t]{3}{*}{$\Delta(\operatorname{Lng}(\operatorname{KSV}(-5)))$} & 3.657616 & -0.136644 & 0.863273 & 3.897015 \\
\hline & $(2.31722)$ & $(0.21136)$ & $(2.17302)$ & $(3.35545)$ \\
\hline & [ 1.57845$]$ & {$[-0.64650]$} & [ 0.39727$]$ & [ 1.16140$]$ \\
\hline \multirow[t]{3}{*}{$\Delta(\operatorname{Ln}(\operatorname{KSV}(-6)))$} & -0.317257 & -0.014473 & 0.038541 & 0.383027 \\
\hline & $(0.21360)$ & $(0.01948)$ & $(0.20031)$ & $(0.30931)$ \\
\hline & {$[-1.48527]$} & {$[-0.74283]$} & [ 0.19241$]$ & [ 1.23834$]$ \\
\hline \multirow[t]{3}{*}{$\Delta(\operatorname{Ln}(\operatorname{KSV}(-7)))$} & -0.003767 & 0.019508 & -0.054708 & -0.129060 \\
\hline & $(0.19926)$ & $(0.01817)$ & $(0.18686)$ & $(0.28853)$ \\
\hline & {$[-0.01890]$} & [ 1.07335$]$ & {$[-0.29278]$} & {$[-0.44730]$} \\
\hline \multirow[t]{3}{*}{$\Delta(\operatorname{Ln}(\operatorname{HCSV}(-4)))$} & 0.382059 & 0.013040 & 0.069430 & 0.143703 \\
\hline & $(0.31867)$ & $(0.02907)$ & $(0.29884)$ & $(0.46145)$ \\
\hline & [ 1.19890$]$ & [ 0.44863$]$ & [ 0.23233$]$ & [ 0.31141$]$ \\
\hline \multirow[t]{3}{*}{$\Delta(\operatorname{Ln}(\operatorname{HCSV}(-5)))$} & 0.425338 & -0.002849 & 0.675730 & 1.179438 \\
\hline & $(0.30356)$ & $(0.02769)$ & $(0.28467)$ & $(0.43957)$ \\
\hline & [ 1.40115$]$ & {$[-0.10288]$} & [ 2.37372] & [ 2.68314] \\
\hline \multirow[t]{3}{*}{$\Delta(\operatorname{Ln}(\operatorname{HCSV}(-6)))$} & -0.027858 & 0.027712 & -0.116777 & -0.193079 \\
\hline & $(0.26256)$ & $(0.02395)$ & $(0.24622)$ & $(0.38020)$ \\
\hline & {$[-0.10610]$} & [ 1.15717$]$ & {$[-0.47428]$} & {$[-0.50784]$} \\
\hline
\end{tabular}


Table 3.3 VECM estimation results of services continued

\begin{tabular}{ccccc}
\hline Error Correction: & $\Delta(\mathbf{L n}(\mathbf{Y S V}))$ & $\Delta(\mathbf{L n}(\mathbf{K S V}))$ & $\Delta(\mathbf{L n}(\mathbf{H C S V}))$ & $\Delta^{\mathbf{2}}(\mathbf{L n}(\mathbf{L S V}))$ \\
\hline \hline$\Delta(\operatorname{Ln}(\operatorname{HCSV}(-7)))$ & 0.009418 & -0.033810 & 0.422834 & 0.472891 \\
& $(0.26517)$ & $(0.02419)$ & $(0.24867)$ & $(0.38398)$ \\
$\Delta^{2}(\operatorname{Ln}(\operatorname{LSV}(-4)))$ & {$[0.03552]$} & {$[-1.39785]$} & {$[1.70038]$} & {$[1.23155]$} \\
& -0.332203 & -0.012525 & 0.043310 & -0.049890 \\
$\Delta^{2}(\operatorname{Ln}(\operatorname{LSV}(-5)))$ & $(0.31527)$ & $(0.02876)$ & $(0.29565)$ & $(0.45653)$ \\
& {$[-1.05370]$} & {$[-0.43554]$} & -0.440552 & {$[-0.10928]$} \\
$\Delta^{2}(\operatorname{Ln}(\operatorname{LSV}(-6)))$ & -0.672466 & 0.006762 & $(0.37889)$ & -1.319631 \\
& $(0.40403)$ & $(0.03685)$ & {$[-1.16276]$} & $(0.58505)$ \\
$\Delta^{2}(\operatorname{Ln}(\operatorname{LSV}(-7)))$ & {$[-1.66440]$} & {$[0.18350]$} & -0.292964 & {$[-2.25558]$} \\
& -0.373337 & -0.011048 & $(0.30156)$ & -0.943117 \\
& $(0.32157)$ & $(0.02933)$ & {$[-0.97149]$} & $(0.46565)$ \\
& {$[-1.16097]$} & -0.658079 & {$[-2.02537]$} \\
& -0.203283 & $0.013068]$ & $(0.15441)$ & -0.906973 \\
& $(0.16466)$ & $(0.01502)$ & {$[-4.26187]$} & $(0.23843)$ \\
& {$[-1.23458]$} & {$[0.87142]$} & 0.001130 & {$[-3.80390]$} \\
& 0.002454 & 0.008494 & $(0.01458)$ & -0.001030 \\
\end{tabular}

\subsection{Services}

In services (Table 3.3), labour played a significant role in the growth of output in the long run, perhaps due to relatively inexpensive cost of labour. Human capital and TFP growth were found positively but insignificantly contributing to its output. The autocorrelation LM test was conducted and no autocorrelation was found.

\subsection{The whole economy}

As expected, the test confirmed one cointegrating relation. The finding interestingly indicated that in the long run the growth of industry can be traded off with those of agriculture and services (Table 4). This finding also indicates the economy jointly determines sectoral productions for the economy in the long run due to limited resources. Most of all, the TFP growth was found to play a significant role to the long run combination of output in the Thai economy. 
Table 4 VECM Estimation results of the economy

\begin{tabular}{|c|c|c|c|}
\hline \multicolumn{4}{|c|}{$\begin{array}{c}\text { Vector Error Correction Estimates } \\
\text { Standard errors in ( ) \& t-statistics in [ ] } \\
\end{array}$} \\
\hline Cointegrating Eq: & CointEq & & \\
\hline $\begin{array}{c}\operatorname{Ln}(Y A G(-1)) \\
\operatorname{Ln}(Y \operatorname{IND}(-1)) \\
\operatorname{Ln}(Y S V(-1)) \\
\text { TREND } \\
\text { C }\end{array}$ & $\begin{array}{c}1.000000 \\
5.605494 \\
(1.46803) \\
{[3.81837]} \\
-11.51238 \\
(1.94187) \\
{[-5.92851]} \\
-0.068901 \\
(0.02968) \\
{[-2.32112]} \\
66.89807 \\
\end{array}$ & & \\
\hline Error Correction: & $\Delta(\operatorname{Ln}(\mathbf{Y A G}))$ & $\Delta(\operatorname{Ln}($ YIND $))$ & $\Delta(\operatorname{Ln}(\mathbf{Y S V}))$ \\
\hline CointEq & $\begin{array}{c}-0.030894 \\
(0.05826) \\
{[-0.53030]}\end{array}$ & $\begin{array}{l}0.014212 \\
(0.02294) \\
{[0.61962]}\end{array}$ & $\begin{array}{l}0.075011 \\
(0.01425) \\
{[5.26412]}\end{array}$ \\
\hline$\Delta(\operatorname{Ln}(\mathrm{YAG}(-4)))$ & $\begin{array}{l}0.901004 \\
(0.05306) \\
{[16.9796]}\end{array}$ & $\begin{array}{c}-0.053368 \\
(0.02089) \\
{[-2.55449]}\end{array}$ & $\begin{array}{c}-0.001337 \\
(0.01298) \\
{[-0.10301]}\end{array}$ \\
\hline$\Delta(\operatorname{Ln}(\mathrm{YIND}(-4)))$ & $\begin{array}{c}-0.699845 \\
(0.45588) \\
{[-1.53514]}\end{array}$ & $\begin{array}{c}0.192182 \\
(0.17949) \\
{[1.07073]}\end{array}$ & $\begin{array}{c}-0.150420 \\
(0.11151) \\
{[-1.34897]}\end{array}$ \\
\hline$\Delta(\operatorname{Ln}(\mathrm{YSV}(-4)))$ & $\begin{array}{l}0.784071 \\
(0.60561) \\
{[1.29468]}\end{array}$ & $\begin{array}{l}0.137191 \\
(0.23844) \\
{[0.57537]}\end{array}$ & $\begin{array}{l}0.384823 \\
(0.14813) \\
{[2.59787]}\end{array}$ \\
\hline $\mathrm{C}$ & $\begin{array}{l}2.867858 \\
(11.0467) \\
{[0.25961]}\end{array}$ & $\begin{array}{l}-0.382539 \\
(4.34924) \\
{[-0.08796]}\end{array}$ & $\begin{array}{l}1.213303 \\
(2.70198) \\
{[0.44904]}\end{array}$ \\
\hline$\Delta(\operatorname{Ln}(\mathrm{KAG}))$ & $\begin{array}{l}-0.067105 \\
(4.90320) \\
{[-0.01369]}\end{array}$ & $\begin{array}{l}-3.855739 \\
(1.93046) \\
{[-1.99732]}\end{array}$ & $\begin{array}{l}-1.450618 \\
(1.19930) \\
{[-1.20955]}\end{array}$ \\
\hline $\operatorname{Ln}(\mathrm{KIND})$ & $\begin{array}{l}-1.067546 \\
(1.39559) \\
{[-0.76494]}\end{array}$ & $\begin{array}{l}0.287739 \\
(0.54946) \\
{[0.52367]}\end{array}$ & $\begin{array}{l}1.097107 \\
(0.34136) \\
{[3.21397]}\end{array}$ \\
\hline $\operatorname{Ln}(\mathrm{KSV})$ & $\begin{array}{l}1.704302 \\
(1.59294) \\
{[1.06991]}\end{array}$ & $\begin{array}{l}-0.301676 \\
(0.62716) \\
{[-0.48102]}\end{array}$ & $\begin{array}{l}-1.110343 \\
(0.38963) \\
{[-2.84976]}\end{array}$ \\
\hline $\log (\mathrm{HCAG})$ & $\begin{array}{l}2.139625 \\
(1.27306) \\
{[1.68070]}\end{array}$ & $\begin{array}{l}0.202727 \\
(0.50122) \\
{[0.40447]}\end{array}$ & $\begin{array}{l}0.565365 \\
(0.31138) \\
{[1.81565]}\end{array}$ \\
\hline Ln(HCIND) & $\begin{array}{c}-0.098450 \\
(1.28306) \\
{[-0.07673]}\end{array}$ & $\begin{array}{c}0.303624 \\
(0.50516) \\
{[0.60105]}\end{array}$ & $\begin{array}{l}0.126514 \\
(0.31383) \\
{[0.40313]}\end{array}$ \\
\hline $\mathrm{Ln}(\mathrm{HCSV})$ & $\begin{array}{c}-1.102053 \\
(0.63849) \\
{[-1.72604]}\end{array}$ & $\begin{array}{c}-0.148416 \\
(0.25138) \\
{[-0.59040]}\end{array}$ & $\begin{array}{c}0.087398 \\
(0.15617) \\
{[0.55963]}\end{array}$ \\
\hline $\operatorname{Ln}(\mathrm{LAG})$ & $\begin{array}{c}-2.110495 \\
(1.35961) \\
{[-1.55228]}\end{array}$ & $\begin{array}{c}0.079876 \\
(0.53530) \\
{[0.14922]}\end{array}$ & $\begin{array}{l}-0.345009 \\
(0.33255) \\
{[-1.03745]}\end{array}$ \\
\hline $\operatorname{Ln}(\mathrm{LIND})$ & $\begin{array}{c}0.231873 \\
(1.21627) \\
{[0.19064]}\end{array}$ & $\begin{array}{c}-0.159455 \\
(0.47886) \\
{[-0.33299]}\end{array}$ & $\begin{array}{c}-0.003996 \\
(0.29750) \\
{[-0.01343]}\end{array}$ \\
\hline$\Delta(\operatorname{Ln}(\operatorname{LSV}))$ & $\begin{array}{l}0.419315 \\
(0.49157) \\
{[0.85300]}\end{array}$ & $\begin{array}{c}0.554418 \\
(0.19354) \\
{[2.86462]}\end{array}$ & $\begin{array}{c}0.302660 \\
(0.12024) \\
{[2.51719]}\end{array}$ \\
\hline
\end{tabular}




\section{CONCLUSION}

In conclusion, the study confirms the concept of endogenous growth hypothesis that the TFP growth can no longer be considered exogenous. If the production function is constructed by including all relevant factor inputs both conventional inputs (physical capital and labour inputs) and human capital including the endogenous TFP growth to be estimated in dynamic model, there is left only the econometric residual or noise. The conventional exogenous TFP growth can partly be explained by some other important factors such as the advancement of knowledge and innovation that are finally applied or utilized by human capital. The estimated TFP growth or the shift of the production function found in this study can mainly be explained by technological progress that is not represented by any other factor of knowledge advancement. Nevertheless, the TFP growth must be estimated by including into the production function at the same time. The findings suggest that some essential input factors that was excluded from the production function, in this case the human capital input, can cause the result of significant findings of the exogenous residual growth.

\section{AUTHOR INFORMATION}

Dr. Paitoon Kraipornsak holds a Master of Economics of Development and Ph.D. (Economics) from The Australian National University. A former economic planner at the National Economic and Social Development Board during 1980 - 1995, he has taught at Chulalongkorn University in Bangkok, Thailand since 1995. He is currently an Associate Professor and Associate Dean at the Faculty of Economics. His research and interest interests are in the areas of macroeconomics, applied econometrics, and economic development. He has extensive research experiences in various economic and statistical applications to applied economic and social policy issues.

\section{REFERENCES}

1. Brimble, P.J. (1987). Total factor productivity growth at the firm level in Thailand: A challenge for the future. Bangkok: Faculty of Economics, Thammasat University (unpublished).

2. Chandrachai, A., B. Tubtimtong, and Chockpisansin, K. (2004). "National Reports: Thailand", in Total Factor Productivity Growth: Survey Report, Tokyo: Asian Productivity Organization.

3. Denison, E.F. (1985), Trend in American Growth, 1929-82, Washington D.C.: Brookings Institution.

4. Kaipornsak, P. (1995). "Sources of economic growth in Thailand: 1970 - 89", The unpublished Ph.D. Thesis, Australian National University, Canberra.

5. Kim, J.I. and L.J. Lau. (1994). "The Sources of Economic Growth of the East Asian Newly Industrialized Countries", Journal of the Japanese and International Economies 8: 235-71

6. Limskul, K. (1988). "Economic development and structural change in Thailand",. The unpublished Ph.D. Thesis, Faculty of Economics, Nagoya University, Japan.

7. Lucas, R.E. (1988). "On the Mechanics of Economic Development”, Journal of Monetary Economics. 22: $3-41$.

8. Mankiew, N.G., D. Romer, and D.N. Weil. (1992). "A Contribution to the Empirics of Economic Growth", Quarterly Journal of Economics 107(2): 407-437.

9. $\quad$ Mincer, J. (1974). Schooling, Experience, and Earnings, New York: Columbia University Press.

10. Romer, P.M. (1990), Endogenous Technological Change”, Journal of Political Economy, Vol 94 (4): 100237.

11. Romer, P.M. (1994), “The Origins of Endogenous Growth”, Journal of Economic Perspectives, Vol 8 (1): $3-22$.

12. Solow, R. (1956), “A Contribution to the Theory of Economic Growth", Quarterly Journal of Economics, Vol. 70 (1): 65 - 94.

13. Solow, R. (1957), “"Technical Change and the Aggregate Production Function", Review of Economics and Statistics, Vol. 39: $312-20$.

14. Tinakorn, P. and Sussangkarn, C. (1998). Total Factor Productivity Growth in Thailand: 1980-1995. Bangkok: Thailand Development Research Institution. 